\title{
Lead bioaccumulation in Opuntia ficus-indica following foliar or root exposure to lead-bearing apatite
}

\author{
El Hayek Eliane ${ }^{\text {a,b,1*}}$; El Samrani Antoine ${ }^{\text {b }}$; Lartiges Bruno ${ }^{\text {a }}$; Kazpard Veronique ${ }^{\text {b }}$ \\ ${ }^{a}$ University of Toulouse (Paul Sabatier), Laboratoire Geosciences Environment Toulouse (UMR \\ CNRS-UPS 5563 IRD 234), 14 Av. Edouard Belin, 31400 Toulouse, France. \\ b Lebanese University, Plateforme de Recherche et d'Analyses en Sciences de 1'Environnement, \\ Ecole Doctorale des Sciences et Technologies, Hadath, Lebanon.
}

\section{*Corresponding author.}

E-mail addresses: elhayek@unm.edu, elianehayek@hotmail.fr

\begin{abstract}
The contamination of edible leafy vegetables by atmospheric heavy metal-bearing particles is a major issue in environmental toxicology. In this study, the uptake of lead by cladodes of Opuntia ficus-indica (Ofi), traditionally used in Mexican cuisine and in livestock fodder, is investigated after a 4-months exposure of either cladodes or roots to synthetic Pb-fluorapatite particles. Atomic Absorption Spectroscopy (AAS) for the quantitative analysis of $\mathrm{Pb}$ levels, Scanning Electron Microscopy coupled with Energy Dispersive X-Ray Spectroscopy (SEM-EDX) for the examination of the cladode surface and fate of particles, and Micro-X-ray fluorescence ( $\mu \mathrm{XRF}$ ) measurements for elemental mapping of $\mathrm{Pb}$ in cladodes, were used. The results evidence that foliar contamination may be a major pathway for the transfer of $\mathrm{Pb}$ within $O f i$ cladodes. The stomata, areoles, and cuticle of cladode surface, play an obvious role in the retention and the incorporation of lead-bearing apatite, thus revealing the hazard of eating contaminated cladodes. The possibility of using series of successive cladodes for biomonitoring the atmospheric pollution in arid and semi-arid regions is also rapidly discussed.

Keywords: Opuntia ficus-indica, foliar or root exposure, Pb uptake, SEM-EDX, $\mu$ XRF.

Capsule: The successive cladodes of Opuntia ficus-indica can be used for biomonitoring of atmospheric pollution
\end{abstract}

\section{Introduction}

\footnotetext{
${ }^{1}$ Present address: Department of Chemistry and Chemical Biology, MSC03 2060, University of New Mexico, Albuquerque, New Mexico 87131, United States
} 
The impact of atmospheric deposition on heavy metals accumulation into the main biosphere compartments (soil, water, plants, etc...) has been widely investigated in the literature (Folkeson, 1979; Jenkis, 1987). Metals in the atmosphere are mostly found associated with organic or inorganic particles possessing an aerodynamic diameter in the 0.01 to $100 \mu \mathrm{m}$ size range (Kabata-Pendias, 2010). Those airborne metal contaminants may cause severe impacts to the human health and the environment (Moriarty, 1999). Air quality monitoring is then crucial for continuous risk assessment and for efficient control of environmental pollution (European Commission, 2002; WHO, 1987). Such monitoring is generally carried out using classical physicochemical techniques complemented by biological monitoring (Garrec and Van Haluwyn, 2002). Indeed, biomonitoring with lichens and mosses has been shown to provide not only an accurate elemental analysis of atmospheric pollution but it has also allowed to characterize the impact of contaminants on biological species (Bargagli and Barghigiani, 1991; Garrec and Van Haluwyn, 2002; Jenkis, 1987; Kabata-Pendias, 2010; Rühling et al., 1987). Other biological matrices such as tree barks (Catinon et al., 2011), mushrooms (Komárek et al., 2007), and several famous vegetables in the kitchen garden (De Temmerman and Hoenig, 2004; Hu et al., 2011; Schreck et al., 2012; Uzu et al., 2010), have also been investigated for such purposes.

Unlike bryophytes and lichens, vascular plants with the possibility of foliar and root exposure may present very different metal transfer pathways (Estrella-Gómez et al., 2009; Honour et al., 2009; Piechalak et al., 2002). Furthermore, the bioaccumulation processes in higher plants may be affected by numerous factors including the metal speciation (Kabata-Pendias, 2010), the plant species (Amblard-Gross et al., 2004; Galsomiès et al., 2003), and the type of exposure to contaminants (Birbaum et al., 2010; Lei et al., 2008). Even though a few models can predict the phytoavailability of trace elements (especially $\mathrm{Cd}, \mathrm{Zn}, \mathrm{Cu}$ and $\mathrm{Pb}$ ) to plant roots, such knowledge remains limited to specific plants growing under given soil conditions (Alexander et al., 2006; McLaughlin, 2001; Mortvedt et al., 1991). In the case of lead, many more studies have failed to evidence a significant link between the $\mathrm{Pb}$ concentration in the soil and in the plant (Jorhem et al., 2000; Murray et al., 2011; Samsøe-Petersen et al., 2002), in comparison with those that have reported consistent results (Bielinska, 2009; Huang et al., 2012). The rather low level of bioavailable $\mathrm{Pb}$ in the soil (Kabata-Pendias and Pendias, 2001) and the significant contribution of atmospheric deposition to plant aerial parts (Douay et al., 2008; Harrison and Chirgawi, 1989) have been assumed to determine the level of $\mathrm{Pb}$ in plants (Mcbride et al., 2014). Indeed, $\mathrm{Pb}$ is generally strongly associated with organic and colloidal soil components, and precipitation reactions mostly at basic pH (Mosbaek et al., 1989), concur to limit its mobility. Moreover, $\mathrm{Pb}$ retained in plant roots as $\mathrm{Pb}$-carbonate precipitate or adsorbed on cell walls (Krzeslowska, 2011), shows very limited mobility to the aerial parts of plants in comparison with the contribution of foliar $\mathrm{Pb}$ (Khan et al., 2008; Prasad and Nazareth, 2000). 
In this study, the bioaccumulation of $\mathrm{Pb}$ by Opuntia ficus-indica (Ofi), a long domesticated cactus that grows in semi-arid regions, is investigated after deliberate contamination of either soil or cladodes by fluorapatite particles enriched with $\mathrm{Pb}$. The contamination conditions were selected according to those encountered in the vicinity of Selaata fertilizer industry (Lebanon) where nearby cactuses are submitted to a large flux of phosphate dust containing various heavy metals (Abi-Ghanem et al., 2009; Aoun et al., 2010). A preliminary $\mathrm{Pb}$ isotopic study revealed that $O f i$ has the ability to record the local atmospheric pollution from the dust deposited onto successive cladodes grown over time (El Hayek et al., 2015). As cladodes represent a significant part of human medicinal and food consumption as well as a source of fodder for cattle and sheep (Ayadi et al., 2009; Corrales-García et al., 2004; De cortazar and Nobel, 1992), a better knowledge of heavy metal bioaccumulation pathways in $O f i$ is crucial. Various stems were then collected from a rural region and contaminated with synthetic $\mathrm{Pb}$-fluorapatite particles either by a direct application on the grown cladodes or by an addition to the cultivation soil. Elemental analysis using Flame Atomic Absorption spectrometry, electron microscopy observation using SEM-EDX, and elemental mapping with SEM-EDX and $\mu$ XRF on resin-embedded samples, were used to identify the transfer pathways of $\mathrm{Pb}$ and the potential of bioaccumulation in $O f i$ following root and foliar exposure to $\mathrm{Pb}$-fluorapatite particles.

\section{Materials and methods}

\subsection{Preparation and characterization of Pb-fluorapatite (Pb-FAP)}

$\mathrm{Pb}$-fluorapatite $(\mathrm{Pb} 17.2 \%)$ was synthetized according to the chemical precipitation method described by Wei et al. (2011) and Laghzizil et al. (2001), that leads to a fluorapatite with two metal cations $\left(\mathrm{Me}^{2+}=\mathrm{Ca}^{2+}+\mathrm{Pb}^{2+}\right.$ and $\left.\mathrm{Me}^{2+} / \mathrm{PO}_{4}{ }^{3-}=1.67\right)$ :

$9 \mathrm{Ca}\left(\mathrm{NO}_{3}\right)_{2}, 4 \mathrm{H}_{2} \mathrm{O}+6\left(\mathrm{NH}_{4}\right)_{2} \mathrm{HPO}_{4}+6 \mathrm{NH}_{4} \mathrm{OH}+2 \mathrm{NaF}+\mathrm{Pb}\left(\mathrm{NO}_{3}\right)_{2}$

$\mathrm{Ca} 9 \mathrm{~Pb}\left(\mathrm{PO}_{4}\right)_{6} \mathrm{~F}_{2}+2 \mathrm{NaNO}_{3}+18 \mathrm{NH}_{4} \mathrm{NO}_{3}+\mathrm{H}_{2} \mathrm{O}$

In practice, a solution containing $102 \mathrm{mmol}$ of $\left(\mathrm{NH}_{4}\right)_{2} \mathrm{HPO}_{4}$ and $34 \mathrm{mmol}$ of $\mathrm{NaF}$, was slowly added to a solution containing $153 \mathrm{mmol}$ of $\mathrm{Ca}\left(\mathrm{NO}_{3}\right)_{2} \cdot 4 \mathrm{H}_{2} \mathrm{O}$ and $17 \mathrm{mmol}$ of $\mathrm{Pb}\left(\mathrm{NO}_{3}\right)_{2}$, the mixture being maintained under stirring at $\mathrm{pH} 10$ using an ammonia solution $(27 \% w t)$. All chemicals purchased from Sigma-Aldrich were of analytical grade and used without further purification. After stirring for $24 \mathrm{~h}$, the suspension was filtered on Whatman paper to recover a gelatinous precipitate, which was subsequently dried at $100{ }^{\circ} \mathrm{C}$ for $2 \mathrm{~h}$. The powder was then thoroughly ground in an agate mortar to obtain the fine particles used in our experiments.

To check the chemical composition of the synthesized powder, Fourier Transform infrared spectroscopy in the transmission mode (FT-IR 6300 JASCO), and X-Ray 
Diffraction (XRD) using $\mathrm{Cu} \mathrm{K} \alpha$ radiation $(\lambda=0.15406 \mathrm{~nm}$ ) (Bruker D8 Diffractometer) and International Center for Diffraction Data (ICDD) to identify the XRD pattern, were used. A mean size of $8 \mu \mathrm{m}$ was obtained for the Pb-fluorapatite using a laser scattering technique (Patrica LA-950V2 Horiba). The particle morphology as well as the $\mathrm{Me}^{2+}$ / $\mathrm{PO}_{4}{ }^{3-}$ elemental ratio were determined using a Scanning Electron Microscope (Jeol JSM 6360LV) equipped with a Silicon Drift Detector (SDD) PGT working at 20kV. All the characterizations performed confirmed the synthesis of stoichiometric $\mathrm{Ca}_{9} \mathrm{~Pb}\left(\mathrm{PO}_{4}\right)_{6} \mathrm{~F}_{2}$ fluorapatite particles. FTIR results, XRD diffractogram, electron micrograph and EDX elemental analysis are presented in the supporting information.

\subsection{Cactuses cultivation and exposure to Pb-fluorapatite}

Ofi cladodes from various remote rural areas in Lebanon were first collected and analyzed for $\mathrm{Pb}$ to obtain pristine cladodes for cultivation (see Table $\mathrm{S} 1$ in Supporting information). The lowest $\mathrm{Pb}$ level found in those cladodes was $4.5 \mathrm{mg} \cdot \mathrm{Kg}^{-1}$ dry weight which usually identifies a Pb-contaminated plant (Markert, 1992; Remon et al., 2013). It is worth noting that $O f i$ is a long-domesticated plant often grown in the vicinity of dwellings, and hence, easily contaminated by anthropogenic activities. Therefore, the 4.5

$\mathrm{mg} \cdot \mathrm{Kg}^{-1}$ concentration served to establish the baseline against which $\mathrm{Pb}$-fluorapatite contamination was assessed.

The soil for $O f i$ cultivation was prepared by thoroughly mixing $2 \mathrm{Kg}$ of natural field soil sieved at $2 \mathrm{~mm}$ with $2 \mathrm{Kg}$ of sand, thus yielding a well-drained potting soil adequate for cactus growth (Drennan and Nobel, 1998). The pH of the soil was almost neutral $\left(\mathrm{pH}_{\text {water }}=7.3\right)$ and contained a low amount of organic matter $(0.78 \%)$. The initial soil $\mathrm{Pb}$ concentration of $17.3 \mathrm{mg} \cdot \mathrm{Kg}^{-1}$ falls in the normal range of uncontaminated soils (Bowen 1979).

The sampled branches of cladodes were rinsed with distilled water to remove any residual dust and then planted separately in plastic pots $(15 \mathrm{~cm}$ diameter and $14 \mathrm{~cm}$ deep soil) according to the common cultivation procedures of cactus represented by methods (a) and (b) (fig. 1): In the method (a), a branch composed of 3 successive cladodes was planted vertically in the soil by driving the portion of its most mature cladode into the soil (cladode 1 in method (a)), whereas in the method (b), a branch composed of only one cladode was placed horizontally on the soil surface. Foliar contamination tests were conducted in triplicate (3 different pots) for both cultivation methods, (a) and (b), by brushing the entire surface of the first cladode in contact with the soil (see fig. 1) with $1 \mathrm{~g}$ of $\mathrm{Pb}$-fluorapatite. Such particle amount is equivalent to that found deposited on cladode surfaces in contaminated areas (El Hayek et al., 2015). The wet brush method used here has been shown to facilitate the deposit of fine particles (Xiong et al., 2014; Muëller et al., 2007) that are more relevant to environmental and health problems (Uzu et al., 2010). 
$\mathrm{Pb}$ uptake by soil-root transfer was assessed by adding $1 \mathrm{~g}$ of $\mathrm{Pb}$-fluorapatite to the sand/field soil mixture using method (a) (3 replicates using branches of 3 successive cladodes in 3 separated pots). Such amount of Pb-FAP permitted to spike the soil with $42.95 \mathrm{mg} . \mathrm{Kg}^{-1}$ of $\mathrm{Pb}$. Although such concentration represents a slight contamination level in comparison with uncontaminated soils (10-30 mg. Kg ${ }^{-1}$ ) (Bowen, 1979), the parallel assessment of foliar and roots behavior under the same exposure conditions restricted the $\mathrm{Pb}$ concentration in the spiked soil. This comes down to the lack of knowledge about how much $\mathrm{Pb}$ can be tolerated by cladodes.

Thus, a total of 15 individual cactuses (fig. 1), including 9 pots for $\mathrm{Pb}$-contamination exposure and 6 pots for blanks ( 3 pots for each method of Ofi cultivation), were then grown for 4 months at ambient temperature $\left(25-35^{\circ} \mathrm{C}\right)$. The cactuses cultivation was conducted in the same rural zone where $O f i$ cladodes had been collected and under the same natural photoperiod. $600 \mathrm{~mL}$ of local mineral water were added every week to each pot to provide adequate watering of cactuses. A 4 months contact period has been shown to be sufficient to reach equilibrium in a natural soil (Alexander et al., 2006; Uzu et al., 2009), and allowed the development of new cladodes and roots on the cultivated cactus plants.

\subsection{Lead analysis in $O f i$ cladodes and roots}

After 4 months, all cladodes and roots were harvested and washed thoroughly first with tap water and then with milli-Q water (18.2 M $\Omega$ ). Prior to washing, the surface of initially contaminated cladodes was cleaned with a wet soft brush to eliminate as many $\mathrm{Pb}$-fluorapatite particles as possible. All cladodes were sliced separately into small cubes $(\sim 2 \mathrm{~cm} \times 2 \mathrm{~cm})$ with a ceramic knife and freeze-dried (Alpha 1-4 LD Christ). A further grinding step using a plastic cooking grinder (Braun) provided a homogeneous fine powder that was sieved at $1 \mathrm{~mm}$ and stored in sealed plastic bags. Roots were first treated with a $1 \mathrm{mM} \mathrm{HCl}$ solution for $3 \mathrm{~min}$ and then a $10 \mathrm{mM} \mathrm{HCl}$ solution for $5 \mathrm{~min}$, to desorb lead present in the outer cell wall layers (Ferrand et al., 2006; Uzu et al., 2009). The cactus roots were then separated using Whatman filter paper, intensively washed with milli-Q water (18.2 M $\Omega$ ) before being oven-dried at $60{ }^{\circ} \mathrm{C}$ for $48 \mathrm{~h}$ and stored in sealed plastic bags.

Each cladode and root sample was digested in triplicate according to Alexander et al. (2006). Briefly, $20 \mathrm{ml}$ of nitric acid (analytical grade) were added to $1 \mathrm{~g}$ of plant material; after about 12 hours, the sample was progressively heated until total dissolution, and then filtered at $0.45 \mu \mathrm{m}$. The lead content of all solutions was determined by flame atomic absorption spectrometry (Rayleigh WFX-210AA). The calibration was performed using certified standard solutions acquired from Fluka-Sigma Aldrich and the detection limit was $0.006 \mathrm{mg} . \mathrm{L}^{-1}$. 
Lead levels measured in roots and cladodes were subjected to separate analysis of variance (ANOVA) tests using Xlstat software (2009). Significant differences $(P<0.05)$ were assessed using the LSD Fisher test.

\subsection{Microscopic observations and spectroscopic analysis}

$\mathrm{X}$-ray microfluorescence $(\mu \mathrm{XRF})$ imaging of cladodes was performed with an EDAX Eagle III XRF system equipped with a polycapillary Rh target excitation source $(20 \mathrm{kV}$, $300-450 \mu \mathrm{A}$ ) and a $\mathrm{Si}(\mathrm{Li})$ detector (resolution of $140 \mathrm{eV}$ ). Elemental $\mu \mathrm{XRF}$ maps were recorded on centimeter size cladode samples with a relatively slow counting time (600$2000 \mathrm{~ms}$ per pixel) and a step size of 30-50 $\mu \mathrm{m}$ (256x200 pixels). The detection limit for heavy metals such as $\mathrm{Pb}$ was around $100 \mathrm{ppm}$. As the $\mathrm{Pb} \mathrm{M}$ and $\mathrm{S} \mathrm{K \alpha} \mathrm{X}$-ray lines overlap, a deconvolution of $\mu \mathrm{XRF}$ spectra was achieved using the EDAX-integrated software Vision32. The $\mathrm{Cl} \mathrm{K \alpha}$ line was also found to interfere with the $\mathrm{Pb} \mathrm{M}$ line and $\mathrm{Pb}$ $(\mathrm{L} \alpha)$ line was then used to follow the lead distribution.

Prior to measurements, cladodes were embedded in an epoxy resin. A $2 \mathrm{~cm} \times 2 \mathrm{~cm}$ piece of cladode was first chemically fixed in $2 \%$ glutaraldehyde for $24 \mathrm{~h}$, before being extensively washed with ultrapure water and dehydrated in a graded series of ethanol and water (from 10 to $100 \%$ ethanol). Ethanol was then exchanged with a graded series of epoxy resin monomers (Lartiges et al., 2001), and the resin-impregnated cladode was polymerized at $60^{\circ} \mathrm{C}$ for $24 \mathrm{~h}$. After embedding, thin slices of cladodes were sectioned using an IsoMet Low Speed Saw machine (15 LC $0.4 \mathrm{~mm}$ ).

Scanning electron microscopy observations were performed with Jeol JSM 6360LV microscope equipped with a Silicon Drift Detector (SDD) PGT working at $20 \mathrm{kV}$. Freeze-dried or resin-embedded cladode pieces were mounted on aluminum stubs and coated with a thin layer of carbon before observation.

\section{Results and discussion}

\subsection{Ofi cultivation in presence of Pb-fluorapatite particles}

After 4 months of foliar and root exposure to $\mathrm{Pb}$-fluorapatite particles, none of the deliberately contaminated $O f i$ showed necroses or any visible toxic effects on the aerial parts of plants. The development of new cladodes (nopalitos) occurred both on contaminated stems and blanks, after 2 weeks of cultivation for cladodes planted vertically and after 3 weeks for cladodes planted horizontally. Nevertheless, the amount of fresh biomass formed, i.e. nopalitos, was about $97 \pm 26.1 \mathrm{~g}$ for Ofi grown in contaminated conditions (roots and foliar exposure), whereas it reached an average of $112.6 \pm 67.5 \mathrm{~g}$ for reference cactuses. Likewise, the total root weight was slightly lower for contaminated $O f i$, i.e. $23.1 \pm 3 \mathrm{~g}$ and $5.1 \pm 1.5 \mathrm{~g}$ for cladodes initially planted 
vertically and horizontally, respectively, whereas the root weight of blanks for the two modes of cultivation reached $37.6 \pm 2.8 \mathrm{~g}$ and $5.8 \pm 0.9 \mathrm{~g}$, respectively. The lower amount of biomass found in contaminated $O f i$ after 4 months of cultivation might be related to the effects of $\mathrm{Pb}$ on the biochemical and physiological metabolisms as described in previous studies (Onder and Dursun, 2006; Sharma and Dubey, 2005; Zeneli et al., 2013). However, the mere presence of fluorapatite particles on the cladode surface, e.g. blocking stomata aperture, may be sufficient to cause disturbances in water exchanges and to inhibit photosynthesis (Farmer, 1993; Hirano et al., 1995). A heavy metal contamination of roots has also been shown to reduce plant growth and to decrease root fresh weight (Perfus-Barbeoch et al., 2002).

\subsection{Lead concentration in cladodes and roots after Pb-fluorapatite exposure}

The average lead content in washed cladodes (mother cladodes and nopalitos) after exposure to $\mathrm{Pb}$-fluorapatite particles is shown in fig. 2 for the two methods of cultivation. In comparison with the control $\left(8 \mathrm{mg} \cdot \mathrm{Kg}^{-1}\right.$ dry weight), the $\mathrm{Pb}$ level was found to be significantly higher $(\mathrm{P}<0.05)$ in cladodes deliberately contaminated, regardless of the cultivation mode. In the case of foliar exposure, the mother cladodes, i.e. cladode 2 vertically planted and cladode 1 horizontally placed, showed the highest $\mathrm{Pb}$ concentrations, i.e. $31.3 \pm 3.7 \mathrm{mg} . \mathrm{Kg}^{-1}$ and $39.5 \pm 2.2 \mathrm{mg} . \mathrm{Kg}^{-1}$, respectively. Despite the thorough washing procedure used in the present study, such high lead concentration might correspond to residual Pb-fluorapatite particles firmly trapped at the surface or inside the cladode. On the other hand, the $\mathrm{Pb}$ concentration in nopalitos remained at levels comparable to reference cladodes after 4 months cultivation, but slightly higher than those of the initial uncontaminated cladodes. Such slight increase might originate from a translocation of lead from the mother cladode to the daughter cladode.

Significantly lower $\mathrm{Pb}$ contamination levels of cladodes (e.g. $14.7 \pm 7 \mathrm{mg} \cdot \mathrm{Kg}^{-1} \mathrm{DW}$ for cladodes 2 planted vertically) were observed in the case of root exposure to Pb-FAP. Even if the modalities of cladode and root exposure to $\mathrm{Pb}$-fluorapatite differs, our results are in line with previous studies indicating that atmospheric deposits on the aerial parts of plants may represent a major contamination pathway for metals (Dalenberg and van Driel, 1990; Feng et al., 2011; Uzu et al., 2010; Xiong et al., 2014). Interestingly, a translocation process in the whole cactus (including the nopalitos that developed during the experiment) took place only for cladodes that were grown on the contaminated soil. Indeed, the amount of lead found in cladodes was twice greater compared with the control stem (cactus (a)). According to Landero Figueroa et al., (2007), such translocation process in Ofi may be attributed to phytochelatines molecules which concentration was shown to significantly increase after lead contamination of the soil. A bioaccumulation of $\mathrm{Pb}$ is of special concern in the case of nopalitos that are commonly used in Mexican cuisine (García Ruiz et al., 2008; Landero Figueroa et al., 2007) and for medicinal 
purpose (Stintzing and Carle, 2005). Indeed, in our experiments, the $\mathrm{Pb}$ concentration in nopalitos was between $4.7-13.3 \mathrm{mg} . \mathrm{Kg}^{-1} \mathrm{DW}$ with having a higher accumulation value in those exposed to roots contamination. Obviously these values exceed the $0.3 \mathrm{mg} \cdot \mathrm{Kg}^{-1}$ fresh weight recommended for edible vegetables in the EU regulations (European Commission, 2002) which is equivalent to $2.58 \mathrm{mg} \cdot \mathrm{Kg}^{-1} \mathrm{DW}$ in the case of cactus (DW represented $8.6 \%$ of nopalitos) .

As for roots contamination, the fig. 3 shows that $\mathrm{Pb}$ concentration only increased significantly when the cultivation soil was contaminated with $\mathrm{Pb}$-fluorapatite particles $\left(\mathrm{Pb}\right.$ value in roots is of $13.2 \pm 1.6 \mathrm{mg} . \mathrm{Kg}^{-1} \mathrm{DW}$, i.e. three times greater than in the control roots). The corresponding cactuses were also the only ones with a fraction of adsorbed lead on the root membrane $\left(1.06 \pm 0.15 \mathrm{mg} \cdot \mathrm{Kg}^{-1} \mathrm{DW}\right)$. Such results underline that foliar exposure was indeed the single transfer pathway for cladodes contaminated with dust deposits. In other terms, no dust deposition or contamination was detected in the virgin soil associated with foliar exposure.

The transfer factor (TF), defined as the ratio of $\mathrm{Pb}$ concentration in plant roots (TF) to that in contaminated soil $\left(42.95 \mathrm{mg} . \mathrm{Kg}^{-1}\right)$, was also calculated. The TF showed relatively low value $(0.22)$ revealing the weak mobility of $\mathrm{Pb}$ in soil, in accordance with previous studies which reported TF values between 0.1 and 0.17 (Khan et al., 2008; Uzu et al., 2009). Moreover, the Global Enrichment Factor (GEF), i.e. the ratio of $\mathrm{Pb}$ concentration in the contaminated plant to the $\mathrm{Pb}$ concentration in the control plant (Chopra and Pathak, 2013; Singh et al., 2010), was found to vary between 1.7 and 5 for roots and foliar exposure, respectively, thus indicating a moderate lead uptake in comparison with other plants exposed to various types of Pb-enriched particles (Schreck et al., 2014; Xiong et al., 2014). However, independently of the morphological characteristics of the cladode surface that obviously play a significant role in the retention of $\mathrm{Pb}$-contaminant particles (Barber et al., 2004; El Hayek et al. 2015), it is worth noting that fluorapatite is a very stable mineral phase (Nriagu, 1974; Smičiklas et al., 2008) which strongly reduces the mobility of lead (Kabata-Pendias and Brümmer, 1992; Laperche et al., 1997). Also of interest is the slight uptake of $\mathrm{Pb}$ by the cactus roots that occurs at a neutral soil $\mathrm{pH}$, a factor known to limit Pb physiological uptake (McBride et al., 2013).

\subsection{Microscopic identification of lead-enriched spots by SEM-EDX}

SEM-EDX examination of the cladodes contaminated with $\mathrm{Pb}$-fluorapatite particles helped identify the potential surface structures participating in the lead retention in $O f i$ (fig. 4). Thus, large areole structures and stomata of around $60 \mu \mathrm{m}$ in diameter play a significant role in the integration of contaminated particles (fig. 4a-f). Such observations are in accordance with previous literature about the role of stomata and trichomes in the foliar pathway of heavy metal uptake (Eichert et al., 2008; Rao and Dubey, 1992; Rucandio et al., 2011; Tomašević et al., 2005; Uzu et al., 2010; Vianna et al., 2011). 
Even following a thorough washing, numerous fluorapatite particles were found simply trapped by the rough surface of cladodes (fig. 4b). Such poor elimination of dust deposits by washing procedures has already been reported in the literature (De Temmerman et al., 2012; Deljanin et al., 2014). In our case, the presence of hydrophobic epicuticular wax and thick rough cuticles obviously contribute to the retention of $\mathrm{Pb}$-fluorapatite particles (Little, 1978; Madany et al., 1990; Birbaum et al., 2010a; Xiong et al., 2014).

As already noted at the macroscopic scale, electron micrographs did not reveal any area of necrosis in the vicinity of contaminant particles. Cabbages, exposed to metal-rich atmospheric deposits, also remained green and healthy which was related to their cuticle thickness (Xiong et al., 2014). In contrast, the smooth surface of lettuces showed significant necrosis after foliar exposition to heavy metal-bearing particles (Grzegorzewski et al., 2010; Schreck et al., 2012; Uzu et al., 2010).

EDX spectra of $\mathrm{Pb}$-fluorapatite particles found on the cladode surface after 4 months cultivation appear identical to those of the initial contaminant particles (see fig. S3 in the supporting information). However, numerous calcium oxalate crystals were observed within stomata and trichomes often in the close vicinity of $\mathrm{Pb}$-fluorapatite particles (fig. 4d). Actually, $O f i$ is considered one of the richest species for calcium oxalate crystals (Nobel, 2002). Such calcium oxalate crystals might promote the dissolution and transformation of heavy metal-bearing deposited dust at the leaf surface (Ehrlich, 1996; Franceschi and Schueren, 1986; Gadd, 2010), although no direct evidence between $\mathrm{Pb}$ bioaccumulation and the presence of calcium oxalate at the surface of cladodes could be found using SEM.

\section{5. $\mu$ XRF analyses}

The distribution of lead in cladode sections embedded in resin was investigated using $\mu \mathrm{XRF}$. Fig. 5 presents the $\mathrm{Pb}, \mathrm{Ca}, \mathrm{P}$ and $\mathrm{K}$ elemental distribution maps of a typical crosssection of both an areole structure and a region comprising the cuticle and parenchyma tissues. A typical $\mu \mathrm{XRF}$ spectrum taken from that zone of interest is shown in fig. $5 \mathrm{~b}$. A $\mathrm{Pb}$-enriched zone that reaches a $300 \mu \mathrm{m}$ depth is observed at the surface of the areole that is distinct from the much more localized $\mathrm{P}$ distribution that identifies $\mathrm{Pb}$-fluorapatite particles. This suggests that some $\mathrm{Pb}$-fluorapatite particles may have been dissolved over time and that $\mathrm{Pb}$ may have diffused inside the areole tissue. Furthermore, the presence of $\mathrm{Pb}$-fluorapatite particles trapped below the cladode surface confirms the ability of $O f i$ to trap permanently atmospheric deposits, which is a key point for its use as a air pollution biomonitor (El Hayek et al., 2015). Indeed, the occurrence of dust particles in the suber tissue of trees (Catinon et al., 2011) and in the upper cortex of lichens (Ayrault et al., 2007) were shown to be a crucial characteristic for a correct assessment of the atmospheric bioaccumulation of contaminants. 
The major cations present in $O f i$ (Nobel, 2002), i.e. Ca and $\mathrm{K}$, were also measured during the $\mu \mathrm{XRF}$ analysis. The elemental maps of those elements show that $\mathrm{Ca}$ and $\mathrm{K}$ are abundant in the cuticle, $\mathrm{Ca}$ being also present as well-defined spots corresponding to calcium oxalate crystals (Nobel, 2002). Similar observations were also made, i.e. Ca, P, $\mathrm{K}$, and metals associated in oxalate crystals, in the trichome structure of tobacco (Sarret et al., 2006). Oxalate crystals are considered as major players in metal detoxification (Franceschi and Schueren, 1986; Sarret et al., 2006). However, further studies are required to extend such role to calcium oxalate crystals in the case of $O f i$.

$\mathrm{X}$-ray elemental mapping of the cladode section embedded in resin by SEM-EDX is in good accordance with that obtained from $\mu \mathrm{XRF}$ analyses (fig. 6). Although the low detection limit of EDX (>1000 ppm for $\mathrm{Pb}$ ) precluded the identification of lead diffusion into the deep layers of the areole structure, the capture of fluorapatite particles from the rough areole surface was nevertheless detected. Indeed, similar $\mathrm{Pb}, \mathrm{P}$ and $\mathrm{Ca}$ elemental maps were obtained in the investigated area, making obvious its significant participation in the integration of airborne particles within the cladode.

\section{Conclusion}

Lead bioaccumulation by Opuntia ficus-indica represents a major toxicological risk to public health in regions where nopalitos are used as food. In this study, SEM-EDX and $\mu \mathrm{XRF}$ observations evidence the incorporation of fluorapatite particles in stomata and trichomes following foliar exposure. Such integration process leads to an increase in $\mathrm{Pb}$ concentration for cladodes contaminated by atmospheric deposits.

Such observations may also explain the differences in $\mathrm{Pb}$ isotopic signatures recorded between successive cladodes (El Hayek et al., 2015); thus each series of cladodes may be used to biomonitor local atmospheric deposits over time. On the other hand, the $\mathrm{Pb}$ fraction that was absorbed by roots was found to spread in the whole stem up to the developing daughter cladodes. Such a contribution is nevertheless significantly lower than that integrated from foliar exposure. Therefore, the possibility of identifying the origin of lead input from the atmosphere (El Hayek et al., 2015), combined with the ability to accumulate atmospheric fallouts on the surface of its cladodes, make Opuntia ficus-indica a promising biomonitor for arid and semi-arid regions.

Acknowledgments: E.E.H. and B.L. would like to thank the University of Toulouse (Paul Sabatier) for funding a thesis joint-supervision grant. E.E.H. and A.E.S. are also grateful to the Lebanese University and the AUF agency in Lebanon (Agence Universitaire de la Francophonie) for providing a significant part of the thesis grant. The authors also wish to thank Thierry Aigouy for help with the SEM at GET and Valérie Magnin for her fruitful cooperation and assistance in $\mu \mathrm{XRF}$ analysis at ISTerre. The authors are also grateful to Professor Ahmad Kobeissi for his help in the experimental part of our study. 


\section{References}

Abi-Ghanem, C., Chiffoleau, J.F., Bermond, a., Nakhlé, K., Khalaf, G., Borschneck, D., Cossa, D., 2009. Lead and its isotopes in the sediment of three sites on the Lebanese coast: Identification of contamination sources and mobility. Appl. Geochemistry 24, 1990-1999. doi:10.1016/j.apgeochem.2009.07.012

Alexander, P.D., Alloway, B.J., Dourado, A.M., 2006. Genotypic variations in the accumulation of $\mathrm{Cd}, \mathrm{Cu}, \mathrm{Pb}$ and $\mathrm{Zn}$ exhibited by six commonly grown vegetables. Environ. Pollut. 144, 736-745.

Amblard-Gross, G., Maul, A., Férard, J.F., Carrot, F., Ayrault, S., 2004. Spatial variability of sampling: grid size impact on atmospheric metals and trace element deposition mapping using mosses. J. Atmos. Chem. 49, 39-52.

Aoun, M., El Samrani, A.G., Lartiges, B.S., Kazpard, V., Saad, Z., 2010. Releases of phosphate fertilizer industry in the surrounding environment: Investigation on heavy metals and polonium-210 in soil. Environ. Sci. 22, 1387-1397.

Ayadi, M.A., Abdelmaksoud, W., Ennouri, M., Attia, H., 2009. Cladodes from Opuntia ficus indica as a source of dietary fiber: effect on dough characteristics and cake making. Ind. Crops Prod. 30, 40-47.

Ayrault, S., Clochiatti, R., Carrot, F., Daudin, L., Bennett, J.P., 2007. Factors to consider for trace element deposition biomonitoring surveys with lichen transplants. Sci. Total Environ. 372, 717-27. doi:10.1016/j.scitotenv.2006.10.032

Barber, J.L., Thomas, G.O., Kerstiens, G., Jones, K.C., 2004. Current issues and uncertainties in the measurement and modelling of air-vegetation exchange and within-plant processing of POPs. Environ. Pollut. 128, 99-138.

Bargagli, R., Barghigiani, C., 1991. Lichen biomonitoring of mercury emission and deposition in mining, geothermal and volcanic areas of Italy. Environ. Monit. Assess. 16, 265-275.

Bielinska, E.J., 2009. Influence of the root layer on the content of cadmium and lead in soils and vegetable plants in regions with diverse anthropogenic impact. J. Res. Appl. Agric. Eng. 54, $16-20$.

Birbaum, K., Brogiolo, R., Schellenberg, M., Martinoia, E., Stark, W., Günther, D., Et, A., 2010. No evidence for cerium dioxide nanoparticle translocation in maize plants. Environ. Sci. Technol. 44, 8718-23.

Bowen, H.J.M., 1979. Environmental Chemistry of the Elements. Academic Press, New York.

Catinon, M., Ayrault, S., Spadini, L., Boudouma, O., Asta, J., Tissut, M., Ravanel, P., 2011. Tree bark suber-included particles: A long-term accumulation site for elements of atmospheric origin. Atmos. Environ. 45, 1102-1109. doi:10.1016/j.atmosenv.2010.11.038

Chopra, A.K., Pathak, C., 2013. Enrichment and translocation of heavy metals in soil and Spinacea oleracea grown in sugar mill effluent irrigated soil. Sugar Tech 15, 77-83.

Corrales-García, J., Peña-Valdivia, C.B., Razo-Martínez, Y., Sánchez-Hernández, M., 2004. Acidity changes and pH-buffering capacity of nopalitos (Opuntia spp.). Postharvest Biol. Technol. 32, 169-174. doi:10.1016/j.postharvbio.2003.11.008 
Dalenberg, J.W., van Driel, W., 1990. Contribution of atmospheric deposition to heavy metal concentration in field crops. Netherlands J. Agric. Sci. 38, 369-379.

De cortazar, V.G., Nobel, P.S., 1992. Biomass and fruit production for the prickly pear cactus, Opuntia ficus indica. J.Am.Soc.Hortic Sci 117, 558-562.

De Temmerman, L., Hoenig, M., 2004. Vegetable crops for biomonitoring lead and cadmium deposition. J. Atmos. Chem. 49, 121-135. doi:10.1007/s10874-004-1219-6

De Temmerman, L., Ruttens, A., Waegeneers, N., 2012. Impact of atmospheric deposition of As, $\mathrm{Cd}$ and $\mathrm{Pb}$ on their concentration in carrot and celeriac. Environ. Pollut. 166, 187-195.

Deljanin, I. V., Tomašević, M.N., Urošević, M.P.A., Antanasijević, D.Z., Perić-Grujić, A.A., Ristić, M., 2014. Lead isotopic composition in tree leaves as tracers of lead in an urban environment. Ecol. Indic. 45, 640-647. doi:10.1016/j.ecolind.2014.05.027

Douay, F., Roussel, H., Pruvot, C., Waterlot, C., 2008. Impact of a smelter closedown on metal contents of wheat cultivated in the neighbourhood. Environ. Sci. Pollut. Res. 15, 162-169.

Drennan, P.M., Nobel, P.S., 1998. Root growth dependence on soil temperature for Opuntia ficus-indica: Influences of air temperature and a doubled $\mathrm{CO} 2$ concentration. Funct. Ecol. 12, 959-964. doi:10.1046/j.1365-2435.1998.00276.x

Ehrlich, H.L., 1996. How microbes influence mineral growth and dissolution. Chem. Geol. 132, 5-9.

Eichert, T., Kurtz, A., Steiner, U., Goldbach, H.E., 2008. Size exclusion limits and lateral heterogeneity of the stomatal foliar uptake pathway for aqueous solutes and watersuspended nanoparticles. Physiol. Plant. 134, 151-160. doi:10.1111/j.13993054.2008.01135.x

El Hayek, E., El Samrani, A., Lartiges, B., Kazpard, V., Benoit, M., Munoz, M., 2015. Potential of Opuntia ficus-indica for air pollution biomonitoring: a lead isotopic study. Environ. Sci. Pollut. Res. 22, 17799-17809. doi:10.1007/s11356-015-4998-1

Estrella-Gómez, N., Mendoza-Cózatl, D., Moreno-Sánchez, R. González-Mendoza, D., ZapataPérez, O., Martínez-Hernández, A., 2009. The Pb-hyperaccumulator aquatic fern Salvinia minima Baker, responds to $\mathrm{Pb} 2+$ by increasing phytochelatins via changes in SmPCS expression and in phytochelatin synthase activity. Aquat. Toxicol. 9, 320-8.

European Commission, 2002. Commission Regulation (EC) No 221/2002 of 6 February 2002 amending regulation (EC) no. 466/2001 setting maximum levels for certain contaminants in foodstuffs.

Farmer, A.M., 1993. The effects of dust on vegetation. A review. Environ. Pollut. 79, 63-75.

Feng, J., Wang, Y., Zhao, J., Zhu, L., Bian, X., Zhang, W., 2011. Source attributions of heavy metals in rice plant along highway in Eastern China. J. Environ. Sci. 23, 1158-64.

Ferrand, E., Dumat, C., Leclerc-Cessac, E., Benedetti, M.F., 2006. Phytoavailability of zirconium in relation to its initial added form and soil characteristics. Plant Soil 287, 313-325. doi:10.1007/s11104-006-9079-2

Folkeson, L., 1979. Interspecies calibration of heavy metal concentrations in nine mosses and lichens: applicability to deposition measurements. Water Air Soil Pollut. 11, 253.

Franceschi, V.R., Schueren, A.M., 1986. Incorporation of strontium into plant calcium oxalate crystals. Protoplasma 130, 199-205. 
Gadd, G.M., 2010. Metals, minerals and microbes: Geomicrobiology and bioremediation. Microbiology 156, 609-643. doi:10.1099/mic.0.037143-0

Galsomiès, L., Ayrault, S., Carrot, F., Deschamps, C., Letrouit-Galinou, M.A., 2003. Interspecies calibration in mosses at regional scale - heavy metal and trace elements results from Ile-deFrance. Atmos. Environ. 37, 241-251.

García Ruiz, M.T., Pena-Valdivia, C.B., Guadarrama, S.V., Corrales-garcía, J., García-nava, R., 2008. Tissue Osmotic Potential and Membranes Permeability of Nopalitos ( Opuntia spp .) Affected by Changes 133-147.

Garrec, J.-P., Van Haluwyn, C., 2002. Biosurveillance végétale de la qualité de l'air. Paris Tec Doc, Lavoisier.

Grzegorzewski, F., Rohn, S., Kroh, L.W., Geyer, M., Schlüter, O., 2010. Surface morphology and chemical composition of lamb's lettuce (Valerianella locusta) after exposure to a lowpressure oxygen plasma. food Chem. 122, 1145-52.

Harrison, R.M., Chirgawi, M.B., 1989. The assessment of air and soil as contributors of some trace metals to vegetable plants. I. Use of a filtered air growth cabinet. Sci. Total Environ. $83,13-34$.

Hirano, T., Kiyota, M., Aiga, I., 1995. Physical effects of dust on leaf physiology of cucumber and kidney bean plants. Environ. Pollut. 89, 255-261.

Honour, S.L., Bell, J.N.B., Ashenden, T.W., Cape, J.N., Power, S.A., 2009. Responses of herbaceous plants to urban air pollution: Effects on growth, phenology and leaf surface characteristics. Environ. Pollut. 157, 1279-1286. doi:10.1016/j.envpol.2008.11.049

Hu, X., Zhang, Y., Luo, J., Xie, M., Wang, T., Lian, H., 2011. Accumulation and quantitative estimates of airborne lead for a wild plant (Aster subulatus). Chemosphere 82, 1351-1357. doi:10.1016/j.chemosphere.2010.11.079

Huang, Z.-Y., Chen, T., Yu, J., Qin, D.-P., Chen, L., 2012. Lead contamination and its potential sources in vegetables and soils of Fujian, China. Environ. Geochem. Heal. 34, 55-65.

Jenkis, D.A., 1987. Trace elements in saxicolous lichens, in Pollutant Transport and Fate in Ecosystems, Coughtrey, P. J., Martin, M. H., and Unsworth, M. H., eds., Blackwell Sci., Oxford 249.

Jorhem, L., Engman, J., Lindeström, L., Schröder, T., 2000. Applications in food quality and environmental contamination: uptake of lead by vegetables grown in contaminated soil. Soil. Sci. Plant Anal. 31, 2403-2411.

Kabata-Pendias, A., 2010. Trace elements in soils and plants, 4th ed. CRC Press, NY.

Kabata-Pendias, A., Brümmer, G.W., 1992. Ecological consequences of As, Cd, $\mathrm{Hg}$ and $\mathrm{Pb}$ enrichment in European soils, in Global Perspective on Lead, Mercury, and Cadmium Cycling in the Environment, Hutchinson, T. C., Gordon C. A., and Meema, K. M., eds., Wiley Eastern Ltd., New Delhi 117-130.

Kabata-Pendias, A., Pendias, H., 2001. Trace Elements in Soils and Plants, 3rd ed. CRC Press, NY.

Khan, S., Aijun, L., Zhang, S., Hu, Q., Zhu, Y.-G., 2008. Accumulation of polycyclic aromatic hydrocarbons and heavy metals in lettuce grown in the soils contaminated with long-term wastewater irrigation. J. Hazard. Mater. 152, 506-515. doi:10.1016/j.jhazmat.2007.07.014 
Komárek, M., Chrastný, V., Stíchová, J., 2007. Metal/metalloid contamination and isotopic composition of lead in edible mushrooms and forest soils originating from a smelting area. Environ. Int. 33, 677-84. doi:10.1016/j.envint.2007.02.001

Krzeslowska, M., 2011. The cell wall in plant cell response to trace metals: polysaccharide remodeling and its role in defense strategy. Acta Physiol Plant 35, 35-51.

Laghzizil, A., El Herch, N., Bouhaouss, A., Lorente, G., Macquete, J., 2001. Comparison of Electrical Properties between Fluoroapatite and Hydroxyapatite Materials. J. Solid State Chem. 156, 57-60. doi:10.1006/jssc.2000.8958

Landero Figueroa, J.A., Afton, S., Wrobel, K., Wrobel, K., Caruso, J.A., 2007. Analysis of phytochelatins in nopal (Opuntia ficus): a metallomics approach in the soil -plant system. J. Anal. At. Spectrom. 22, 897. doi:10.1039/b703912c

Laperche, V., Logan, T.J., Gaddam, P., Traina, S.J., 1997. Effect of apatite amendments on plant uptake of lead from contaminated sail. Environ. Sci. Technol. 31, 2745-2753. doi:10.1021/es961011o

Lartiges, B.S., Deneux-Mustin, M., Babut, S., Villemin, G., Mustin, C.., Barrès, O., Chamerois, M., Gerard, B., 2001. Composition, structure and size distribution of suspended particulates from the Rhine River. Water Res. 35, 808-816.

Lei, M., Chen, T.B., Huang, Z.C., Wang, Y.D., Huang, Y.Y., 2008. Simultaneous compartmentalization of lead and arsenic in co-hyperaccumulator Viola principis $\mathrm{H}$. de Boiss.: an application of SRXRF microprobe. Chemosphere 72, 1491-6.

Little, P.E., 1978. Deposition of exhaust lead and its impact on plants. Symposium " The impact of road traffic on plants."

Madany, I., Ali, S., Akhter, M., 1990. Assessment of lead in roadside vegetation in Bahrain. Environ. Int. 16, 123-6.

Markert, B., 1992. Establishing of "reference plant" for inorganic characterization of different plant species by chemical fingerprint. Water, Air Soil Pollut. 64, 533-538.

Mcbride, M.B., Shayler, H.A., Spliethoff, H.M., Mitchell, R.G., Marquez-bravo, L.G., Ferenz, G.S., Russell-anelli, J.M., Casey, L., Bachman, S., 2014. Concentrations of lead , cadmium and barium in urban garden-grown vegetables: The impact of soil variables. Environ. Pollut. 194, 254-261. doi:10.1016/j.envpol.2014.07.036

McBride, M.B., Simon, T., Tam, G., Wharton, S., 2013. Lead and arsenic uptake by leafy vegetables grown on contaminated soils: Effects of mineral and organic amendments. Water. Air. Soil Pollut. 224, 1378. doi:10.1007/s11270-012-1378-Z

McLaughlin, M.J., 2001. Bioavailability of metals to terrestrial plants, in: Allen, H.E. (Ed.), Bioavailability of Metals in Terrestrial Ecosystems. Importance of Partitioning for Bioavailability to Invertebrates, Microbes and Plants. SETAC Press, Pensacola, FL, pp. 39 68.

Moriarty, F., 1999. Ecotoxicology - the study of pollutants in ecosystems, 3rd editio. ed. San Diego.

Mortvedt, J.J., Cox, F.R., Shuman, L.M., Welch, R.M., 1991. Micronutrients in Agriculture, 2nd ed. Soil Sci. Soc. Am., Madison, WI.

Mosbaek, H., Tjell, J.C., Hovmand, M.F., 1989. Atmospheric lead input to agricultural crops in 
Denmark. Chemosphere 19, 1787-1799.

Muëller, D., Mattis, I., Kolgotin, A., Ansmann, A., Wandinger, U., Althausen, D., 2007. Characterization of atmospheric aerosols with multiwavelength Raman lidar. Proc. SPIE 6750 .

Murray, H., Pinchin, T.A., Macfie, S.M., 2011. Compost application affects metal uptake in plants grown in urban garden soils and potential human health risk. J. Soils Sediments 11, $815-829$.

Nobel, P.S., 2002. Cacti biology and uses. University of California Press.

Nriagu, J.O., 1974. Lead orthophosphates-IV Formation and stability in the environment. Geochim. Cosmochim. Acta 887-898.

Onder, S., Dursun, S., 2006. Air borne heavy metal pollution of Cedrus libani (A. Rich.) in the city centre of Konya (Turkey). Atmos. Environ. 40, 1122-1133.

Perfus-Barbeoch, L., Leonhardt, N., Vavasseur, A., Forestier, C., 2002. Heavy metal toxicity: cadmium permeates through calcium channels and disturbs the plant water status. Plant J. 32, 539-548. doi:10.1046/j.1365-313X.2002.01442.x

Piechalak, A., Tomaszewska, B., Baralkiewicz, D., Malecka, A., 2002. Accumulation and detoxification of lead ions in legumes. Phytochemistry 60, 153-62.

Prasad, L.R., Nazareth, B., 2000. Contamination of allotment soil with lead: managing potential risks to health. J. Public Heal. 22, 525-530.

Rao, M., Dubey, P., 1992. Occurrence of heavy metals in air and their accumulation by tropical plants growing around an industrial area. Sci. Total Environ. 126, 1-16.

Remon, E., Bouchardon, J.L., Le Guédard, M., Bessoule, J.J., Conord, C., Faure, O., 2013. Are plants useful as accumulation indicators of metal bioavailability? Environ. Pollut. 175, 1-7. doi:10.1016/j.envpol.2012.12.015

Rucandio, M.I., Petit-Domínguez, M.D., Fidalgo-Hijano, C., García-Giménez, R., 2011. Biomonitoring of chemical elements in an urban environment using arboreal and bush plant species. Environ. Sci. Pollut. Res. 18, 51-63. doi:10.1007/s11356-010-0350-y

Rühling, A., Rasmussen, L., Pilegaard, K., Mäkinen, A., Steinnes, E., 1987. Survey of Atmospheric Heavy Metal Deposition in Nordic Countries in 1985.

Samsøe-Petersen, L., Larsen, E.H., Larsen, P.B., Bruun, P., 2002. Uptake of trace elements and PAHs by fruit and vegetables from contaminated soils. Environ. Sci. Technol. 36, 30573063.

Sarret, G., Harada, E., Choi, Y.-E., Isaure, M.-P., Geoffroy, N., Fakra, S., Marcus, M.A., Birschwilks, M., Clemens, S., Manceau, A., 2006. Trichomes of tobacco excrete zinc as zinc-substituted calcium carbonate and other zinc-containing compounds. Plant Physiol. 141, 1021-1034. doi:10.1104/pp.106.082743

Schreck, E., Dappe, V., Sarret, G., Sobanska, S., Nowak, D., Nowak, J., Stefaniak, E.A., Magnin, V., Ranieri, V., Dumat, C., 2014. Foliar or root exposures to smelter particles: consequences for lead compartmentalization and speciation in plant leaves. Sci. Total Environ. 476-477, 667-76. doi:10.1016/j.scitotenv.2013.12.089

Schreck, E., Foucault, Y., Sarret, G., Sobanska, S., Cécillon, L., Castrec-Rouelle, M., Uzu, G., Dumat, C., 2012. Metal and metalloid foliar uptake by various plant species exposed to 
atmospheric industrial fallout: mechanisms involved for lead. Sci. Total Environ. 427-428, 253-62. doi:10.1016/j.scitotenv.2012.03.051

Sharma, P., Dubey, R., 2005. Lead toxicity in plants. Braz J Plant Physiol 17, 35-52.

Singh, R., Singh, D.P., Kumar, N., Bhargava, S.K., Barman, S.C., 2010. Accumulation and translocation of heavy metals in soil and plants fromfly ash contaminated area. J. Environ. Biol. 31, 421-30.

Smičiklas, I., Onjia, A., Raičević, S., Janaćković, Đ., Mitrić, M., 2008. Factors influencing the removal of divalent cations by hydroxyapatite. J. Hazard. Mater. 152, 876-884.

Stintzing, F.C., Carle, R., 2005. Cactus stems (Opuntia spp.): A review on their chemistry, technology and uses. Mol. Nutr. Food Res. 49, 175-194.

Tomašević, M., Vukmirović, Z., Rajšić, S., Tasić, M., Stevanović, B., 2005. Characterization of trace metal particles deposited on some deciduous tree leaves in an urban area. Chemosphere 61, 753-760. doi:10.1016/j.chemosphere.2005.03.077

Uzu, G., Sobanska, S., Aliouane, Y., Pradere, P., Dumat, C., 2009. Study of lead phytoavailability for atmospheric industrial micronic and sub-micronic particles in relation with lead speciation. Environ. Pollut. 157, 1178-85. doi:10.1016/j.envpol.2008.09.053

Uzu, G., Sobanska, S., Sarret, G., Munoz, M., Dumat, C., 2010. Foliar lead uptake by lettuce exposed to atmospheric fallouts. Environ. Sci. Technol. 44, 1036-42.

Vianna, N.A., Gonçalves, D., Brandão, F., de Barros, R.P., Filho, G.M.A., Meire, R.O., Torres, J.P.M., Malm, O., Júnior, A.D., Andrade, L.R., 2011. Assessment of heavy metals in the particulate matter of two Brazilian metropolitan areas by using Tillandsia usneoides as atmospheric biomonitor. Environ. Sci. Pollut. Res. 18, 416-427. doi:10.1007/s11356-010$0387-y$

Wei, W., Zhang, X., Cui, J., Wei, Z., 2011. Interaction between low molecular weight organic acids and hydroxyapatite with different degrees of crystallinity. Colloids Surfaces A Physicochem. Eng. Asp. 392, 67-75. doi:10.1016/j.colsurfa.2011.09.034

WHO, 1987. Air Quality Guidelines for Europe European Series.

Xiong, T.-T., Leveque, T., Austruy, A., Goix, S., Schreck, E., Dappe, V., Sobanska, S., Foucault, Y., Dumat, C., 2014. Foliar uptake and metal(loid) bioaccessibility in vegetables exposed to particulate matter. Environ. Geochem. Health 36, 897-909. doi:10.1007/s10653-014-9607-6

Zeneli, L., Daci-Ajvazi, M., Daci, N.M., Hoxha, D., Shala, A., 2013. Environmental Pollution and Relationship Between Total Antioxidant Capacity and Heavy Metals ( $\mathrm{Pb}, \mathrm{Cd}, \mathrm{Zn}, \mathrm{Mn}$, and Fe) in Solanum tuberosum L. and Allium cepa L. Hum. Ecol. Risk Assess. An Int. J. 19, 1618-1627. doi:10.1080/10807039.2012.708268 